\title{
Social support, socioeconomic and clinical risk: comparison between to neighborhoods in a Brazilian upcountry town
}

\author{
APOIO SOCIAL, RISCO SOCIOECONÔMICO E CLÍNICO: COMPARAÇÃO ENTRE \\ BAIRROS EM CIDADE DO INTERIOR DO BRASIL
}

\section{APOYO SOCIAL, RIESGO SOCIOECONÓMICO Y CLÍNICO: COMPARACIÓN ENTRE BARRIOS EN CIUDAD DEL INTERIOR DE BRASIL}

\author{
Milce Burgos Ferreira1, Marilene Rivany Nunes², Geraldo Cássio dos Reis ${ }^{3}$, Mônica de Andrade \\ Morraye $^{4}$, Semiramis Melani de Melo Rocha ${ }^{5}$
}

\begin{abstract}
The objective of this study was to compare the perceptions of two families living in two different neighborhoods (rated according to risk levels) regarding social support. A questionnaire was designed to assess social support according to the following dimensions: instrumental, emotional, religious, and support from friends, neighbors and family. The sample was comprised as follows: considering the 114 families living in neighborhood 1, 52 families were interviewed; and among the 162 families living in neighborhood 2, 60 families were interviewed. No significant difference was found related to instrumental, religious and emotional support, including the support from relatives among the families from both neighborhoods. The results disagree with the reviewed literature, which indicated a strong association between social support and families living at socioeconomic risk. In conclusion, social support is important for families, regardless of their risk stratification.
\end{abstract}

\section{DESCRIPTORS}

Family

Social support

Risk groups

Health Promotion

Socioeconomic factors

\section{RESUMO}

O objetivo deste estudo foi comparar a percepção sobre apoio social entre famílias residentes em dois diferentes bairros, classificadas em graus de risco. Foi desenvolvido um questionário para avaliar o apoio social desmembrado nas dimensões instrumental, emocional, religiosa e de apoio de amigos, vizinhos e família. A amostra constitui-se da seguinte maneira: entre as 114 famílias residentes no bairro 1 , foram entrevistadas 52, e entre as 162 residentes no bairro 2, foram entrevistadas 60 famílias. Não houve diferença significante em relação ao apoio instrumental, religioso, emocional e o recebido de familiares entre os residentes nos dois bairros. Os resultados apresentaram discordância com a literatura revisada, que indicava forte associação entre apoio social e famílias expostas a riscos socioeconômicos. Consideramos que apoio social é importante para as famílias, independentemente de sua condição de risco.

\section{DESCRITORES \\ Família \\ Apoio social \\ Grupos de risco \\ Promoção da Saúde \\ Fatores socieconômicos}

\section{RESUMEN}

El objetivo de este estudio fue comparar la percepción sobre apoyo social entre familias residentes de dos barrios diferentes, clasificados según grado de riesgo. Fue desarrollado un cuestionario para evaluar el apoyo social, dividiéndolo en las dimensiones: instrumental, emocional, religioso y apoyo de amistades, vecinos y familia. Muestra: de las 114 familias residentes en el barrio 1 , fueron entrevistadas 52 , y entre las 162 residentes en el barrio 2, se entrevistaron 60. No existió diferencia significativa entre los residentes de ambos barrios. Los resultados mostraron discordancia con la literatura revisada, que expresaba fuerte asociación entre apoyo social y familias expuestas a riesgo socioeconómico. Consideramos que el apoyo social es importante para las familias, independientemente de su condición de riesgo.

\section{DESCRIPTORES \\ Familia \\ Apoyo social \\ Grupos vulnerables \\ Promoción de Salud \\ Factores socioeconómicos}

\footnotetext{
${ }^{1}$ Master's Degree in Health Promotion, Lecturer at Patos de Minas College. Patos de Minas, MG, Brazil. milceb@yahoo.com.br ${ }^{2}$ Master's Degree in Health Promotion, Lecturer at Patos de Minas College. Patos de Minas, MG, Brazil. maryrivany@yahoo.com.br ${ }^{3}$ Statistician in University of São Paulo at Ribeirão Preto School of Medicine of University of São Paulo. Ribeirão Preto, SP, Brazil. gcreis@fmrp.usp.br ${ }^{4}$ PhD in Science, Professor at University of Franca. Franca, SP, Brazil. monica@unifran.br ${ }^{5} \mathrm{PhD}$ in Nursing, Rho Upsilon Chapter, Full Professor at University of São Paulo at Ribeirão Preto College of Nursing and Professor at University of Franca. Ribeirão Preto, SP, Brazil. smmrocha@eerp.usp.br
} 


\section{INTRODUÇÃO}

Empirical studies have shown that a relationship exists between social support, socioeconomic conditions and health promotion in different populations ${ }^{(1-3)}$. People at lower socioeconomic levels have smaller networks. They exchange support with fewer people and may be less satisfied with the support they receive ${ }^{(4-5)}$. A community with high levels of civic engagement, social participation, social interaction, high levels of trust, political equality and social structures that serve to enhance cooperation between citizens, is characterized as a community with high social capital(6). The concept of social support is part of several theoretical frameworks and practice models. Several authors consider social support a temporal term, that is, its meaning can vary over one's course of life ${ }^{(1)}$. The presence of a strong social network and social support often improves family members' health status and life satisfaction. Families have affective, reproductive, economic, and health functions that greatly impact the lives of individual members. Family risk condition is defined as dysfunction in the structure, functions, and processes as caused by limited resources, multiple problems and less-educated members. Families in conditions of risk are more vulnerable ${ }^{(7)}$.

\section{BACKGROUND}

Brazilian people, including families as a whole, have been changing, according to historic, economic, social, and demographic transformations during the last century ${ }^{(8)}$. Brazil has severe inequalities in its distribution of wealth and a large part of its population lives in poverty without access to goods essential to good health. The main determinants of these inequalities are related to the ways social life is organized, as influenced by global factors of a social, economic, and political nature, indirectly impacting on the health of groups and people ${ }^{(9)}$. To improve the quality of the services offered by the Public Health System, the Brazilian government implemented the Family Health Strategy ${ }^{(10)}$, targeting the health of individuals in the context of their families and their community. The focus is health promotion. This strategy was developed as a master plan of primary health care in order to reorganize the public service network, and is characterized by planning, organizing, and monitoring actions intended to obtain better health indices and improve the quality of health care. Family members living in communities are registered and classified through indicators of socioeconomic and clinical risks. This method classifies families by levels of risk, which indicates the real needs of families ${ }^{(11)}$.

\section{Aims}

The aims of this study were to compare the level of family risk and perceived social support of two neighborhoods in upcountry Brazil, and examine the interrelationships between level of family risk and social support.

\section{METHOD}

\section{Design}

This was a pilot study, based on a random sample survey carried out in two neighborhoods in upcountry Brazil. Surveys are the design of choice for descriptive quantitative research questions or when we want to look for associations between measurable variables. The logic of survey design is rooted in a positivist epistemology, in which the aim of research is explanation. Not all research questions are about cause and effect. This study examined two variables: families' risk conditions and social support perceived by family members. There are currently many instruments designed to measure social support, however, an instrument that could specifically identify friends, neighbors and family members as sources of support was not found in the literature, nor even an instrument addressing the perception of family members related to spiritual or religious support. For this reason, and also considering that these sources of support are very important in Brazilian culture, an instrument found in the literature and already validated for Brazilian Portuguese was adapted for this study.

\section{Setting and sample}

The location of the study was an upcountry town in Minas Gerais with 138,466 inhabitants. The Public Family Health Service was implemented in 2002 and attends $70 \%$ of the population, using 26 health professional teams. The Primary Care Family Health Service Unit (PCFHSU) selected for this study cares for 1259 families, living in 8 micro-neighborhoods. Two neighborhoods were selected for this study.

A simple random sampling, without replacement, but with stratification for the variables socioeconomic and clinical risks, was used to select the participants, considering a confidence level of $95 \%$ and sample error of $10 \%$ (Table 1). In neighborhood 1, from a total of 114 families, 52 families were drawn and, in neighborhood 2, from 162 families, 60 families were drawn. 
Table 1 - Number of families according to the level of socioeconomic and clinical risk and sampling of Neighborhoods 1 and 2 , Brazilian upcountry town -2009

\begin{tabular}{lcccccc}
\hline \multirow{2}{*}{ Risk } & \multicolumn{3}{c}{ Neighborhood 1 } & \multicolumn{2}{c}{ Neighborhood 2 } \\
\cline { 2 - 6 } & $\mathbf{N}$ & $\mathbf{\%}$ & Sample & N & \% & Sample \\
\hline No risk & 77 & 67.5 & 35 & 0 & 0 & 0 \\
Low & 23 & 20.2 & 10 & 20 & 12.3 & 8 \\
Medium & 13 & 11.4 & 6 & 80 & 49.9 & 38.3 \\
High & 1 & - & 1 & 62 & 23 & 100 \\
\hline Total & 114 & 100 & 52 & 162 & 60 \\
\hline
\end{tabular}

$\mathrm{N}$ : Number of families living and registered in the neighborhoods. Sample: Number of selected families.

\section{Ethical considerations}

Ethical approval was obtained from the Research Ethics Committees of the University of Franca (Process number 161/08) and institutional permission and access were jointly obtained from the Primary Care Family Health Service Unit utilized in this study. Informed written consent was obtained from all adult participants and children older than 12 years of age. We got parental permission to include the children. Participants were also ensured confidentiality and the possibility to refuse answering any question or to withdraw from the study at any time.

\section{Measures}

\section{Scale of socioeconomic and clinical risk}

All families that attended the Primary Care Family Health Service Unit (PCFHS) usually are classified according to a scale of socioeconomic and clinical risk, according to an instrument used by health professionals in the School of Public Health of Minas Gerais, Brazil(11). This instrument correlated two variables: socioeconomic and clinical.

The socioeconomic indicators of families at risk were: families whose head is illiterate; families in extreme poverty with monthly per capita income under $\mathrm{R} \$ 60.00$ ( $R \$$ 60.00 is equivalent to US\$ 35.00 according to the exchange rate in October 2010; and absence of appropriate water supply. The classification of socioeconomic risks is as follows: none of the risk factors $=0$, presence of one of the risk factors $=1$, two risk factors $=2$, and three or more risk factors $=3$.
The indicators of family clinical risk were: children at risk: underweight; preterm; severe malnutrition; positive neonatal screening for hypothyroidism; phenylketonuria, anemia, cystic fibrosis; diseases of vertical transmission such as toxoplasmosis, syphilis, AIDS; important intercurrences during the neonatal period; inadequate growth and development and unfavorable development of any disease; adolescents at high risk: sexually transmissible diseases; early pregnancy; eating disorders, use and abuse of legal and illegal substances, victim of sexual exploitation, depression, mental disorders, adolescents who ran away from home or lived on the streets; adults at high risk: hypertension, diabetes, tuberculosis, leprosy or at risk of serious mental disease; pregnant women: drug-users of legal or illegal drugs, previous perinatal death, habitual abortion, infertility, preeclampsia, eclampsia, gestational diabetes, labor with fetal death, heart disease, kidney disease, blood disorders, hypertension, bleeding during pregnancy; elderly over 80 years; elderly over 60 years with several pathologies, using many medications, with total or partial immobility, urinary or fecal incontinence, postural instability, cognitive impairment; with frequent hospitalizations, depending on help to perform daily basic tasks and living alone or in homes ${ }^{(11)}$. The clinical risk factors are scored as follows: none of the family members had the clinical risk condition $=0$; only one of the members was at clinical risk =1; two or more members were at risk $=2$; one or more members had concomitantly two or more clinical conditions $=3$.

The level of family risk was measured by means of the sum of two scores: socioeconomic factors and clinical conditions, which defines the final score. Subsequently, scores were interpreted and families were classified as at no risk, low risk, medium risk, or high risk (Table 2).

Table 2 - Criteria to classify families according to the level of socioeconomic and clinical risks

\begin{tabular}{|c|c|c|c|c|c|}
\hline \multirow[b]{2}{*}{ Final score for risk classification } & \multicolumn{5}{|c|}{ Socioeconomic criteria } \\
\hline & & No risk factor & 1 or 2 risk factors & $\begin{array}{l}2 \text { or more risk } \\
\text { factors }\end{array}$ & $\begin{array}{c}3 \text { or more risk } \\
\text { factors }\end{array}$ \\
\hline Clinical Criteria & $\mathrm{P}$ & 0 & 1 & 2 & 3 \\
\hline None of the members have any condition or pathology & 0 & 0 & 1 & 2 & 3 \\
\hline Only 1 member has 1 condition or pathology & 1 & 1 & 2 & 3 & 4 \\
\hline 2 or more members have 1 condition or pathology & 2 & 2 & 3 & 4 & 5 \\
\hline $\begin{array}{l}1 \text { or more members concomitantly have } 2 \text { or more } \\
\text { conditions or pathologies }\end{array}$ & 3 & 3 & 4 & 5 & 6 \\
\hline
\end{tabular}

Source: Escola de Saúde Pública do Estado de Minas Gerais (ESPMG); 2008(11)

Social support, socioeconomic and clinical risk: comparison between to neighborhoods in a Brazilian upcountry town Ferreira MB, Nunes MR, Reis GC, Morraye MA, Rocha SMM 


\section{Social support survey}

Social support is usually defined as the existence or availability of people whom one can rely on, people who let one know that they care about, value, and love him or her. Social networks are generally understood in structural terms, focused on the structural underpinning of support, and described as linking to and interacting with surrounding social institutions like family, neighborhood and other organizations $^{(1,15)}$. Social support requires the existence of social relationships that vary according to structure, strength, type and some conditions, such as reciprocity, accessibility and mutual confidence; social relations provide for inclusion, as well as emotional, material and cognitive resources, among others. As a result of social bonds, individuals can remove themselves somewhat from their problems; giving information is inherent to all support resources; interactions can occur intentionally or unintentionally and can exert a positive or negative influence, which is affected by the acknowledgement of individual needs and how support is perceived; it depends on characteristics of who offers and receives support ${ }^{(14-16)}$. For research purposes, one has to select a concept that includes relevant aspects, coherent with the objective to be achieved.

One way to address social support is to break it into its components and evaluate its different dimensions in their contribution to health. Social support, defined as the level at which interpersonal relationships correspond to certain functions, can be broken down into four classes: appraisal, emotional, informational and instrumental support. Appraisal support refers to expressions and feelings of acknowledgement; emotional support refers to affection, love, empathy, respect; the informational category is related to suggestions, information, advice and opinions; and instrumental support refers to financial help, time dedicated to helping and the availability of resources, goods and services ${ }^{(14)}$. In addition to family, friends and neighbors, social support can also take the form of organized community involvement. Faith, religion and spirituality are considered important resources for strengthening the family to cope with moments of crisis $^{(14)}$.

We developed an instrument modified from MOS_SSS, adapted for Brazilian Portuguese ${ }^{(15-17)}$. The first section contains 13 items, including item: "benefits received from the National Institute of Social Security" (NISS) - an agency of the Brazilian Ministry of Social Security. This agency provides income resources to workers and their families when they temporarily (due to disease, accident, maternity) or permanently (death, disability and old age) lose their capacity to work.

The second section, the family support dimension, contains six items designed to measure whether family members trusted each other, respected each other's privacy, gathered to celebrate dates, had fun, talked to each other, and believed the family was capable of giving support in difficult situations. In the third section, related to faith and religious support, we investigated whether family members belonged to any religious group and had any religious beliefs. Five questions addressed religious support. We were interested in knowing whether faith and religions had served as sources of support. The emotional support dimension contained eight items that measured the expression of affection, empathetic understanding, and the expressing of feelings.

Answers were limited to a choice among three alternatives for each question; answers were: Yes (score=2), Sometimes (score $=1$ ) and No (score=0).

The questionnaire was examined by three behavioral scientists, who made few changes to establish the appropriate social support category for each of the items. Based on the perspective of the Family Nursing theoretical framework ${ }^{(18)}$, we applied the questionnaire to all family members, randomly drawn from the sample, excluding children younger than 12 years of age.

\section{Questionnaire distribution}

Researchers made contact with families and explained the study's objectives and its importance to all family members. The most convenient days and times to apply the questionnaire were also scheduled. The questionnaire was applied through face-to-face interviews, carried out between January and February 2009 at the participants' homes, since these were considered an environment favorable to the interview. All those living in the home registered in the Family Health Unit's file were considered family members. The first researcher recorded the answers.

\section{Data analysis}

Data were stored in two Microsoft Office Excel spreadsheets, which registered a total 126 responses, corresponding to the families living in neighborhood 1 , and 164 responses corresponding to the families living in neighborhood 2. In the second spreadsheet, the average between the values attributed and the number of family participants was registered for each study variable. This file totaled the register of 52 responses, corresponding to the families living in neighborhood 1, and 60 responses corresponding to the families living in neighborhood 2 . First, descriptive statistics and preliminary analyses were performed. The non-parametric Kruskal-Wallis (ANOVA) test, the $\mathrm{X} 2$ and post hoc Dunn test were used to compare variables within the neighborhoods between risk groups. The non-parametric Mann-Whitney test was used to compare variables between the two neighborhoods. A significance level of $p \leq 0.05$ was adopted.

\section{RESULTS}

Table 3 presents the results related to support received from the National Institute of Social Security (INSS).

Table 4 presents the estimation of social support received according to the four dimensions. 
Table 3 - Benefits from the INSS estimated by families of Neighborhoods 1 and 2 in a Brazilian upcountry town - 2009

\begin{tabular}{|c|c|c|c|c|c|c|}
\hline \multirow[b]{2}{*}{$\begin{array}{l}\text { National Institute of Social Secu- } \\
\text { rity - Benefit - INSS }\end{array}$} & \multicolumn{3}{|c|}{ Neighborhood 1} & \multicolumn{3}{|c|}{ Neighborhood 2} \\
\hline & $\begin{array}{l}\text { Number of } \\
\text { families }\end{array}$ & $\%$ & $\%$ Valid & $\begin{array}{c}\text { Number of } \\
\text { families }\end{array}$ & $\%$ & $\begin{array}{c}\% \\
\text { Valid }\end{array}$ \\
\hline No & 38 & 73.1 & 74.5 & 37 & 61.7 & 62.7 \\
\hline Yes & 13 & 25.0 & 25.5 & 22 & 36.7 & 37.3 \\
\hline Total & 51 & 98.1 & 100.0 & 59 & 98.3 & 100.0 \\
\hline No answer & 1 & 1.9 & 0 & 1 & 1.7 & 0 \\
\hline Total & 52 & 100.0 & 100 & 60 & 100.0 & 100 \\
\hline
\end{tabular}

Table 4 - Social support estimated by families from the Neighborhoods 1 and 2 in a Brazilian upcountry town - 2009

\begin{tabular}{lcccccccc}
\hline \multirow{2}{*}{ Types of Support } & \multicolumn{3}{c}{ Neighborhood 1 } & \multicolumn{3}{c}{ Neighborhood 2 } & \multicolumn{2}{c}{ Values } \\
\cline { 2 - 7 } & M & MD & SD & A & MD & SD & Min & Max \\
\hline Religious Support & 7.76 & 8.00 & 1.82 & 7.86 & 8.00 & 1.59 & 2.00 & 10.00 \\
Emotional Support & 14.19 & 15.50 & 2.90 & 14.04 & 15.33 & 2.98 & 2.00 & 26.00 \\
Support from friends and neighbors & 4.74 & 5.00 & 2.45 & 3.87 & 2.30 & 2.30 & 0.00 & 8.00 \\
Family Support & 9.79 & 11.00 & 2.61 & 10.20 & 11.00 & 2.39 & 2.5 & 12.00 \\
\hline
\end{tabular}

$\mathrm{M}=$ mean; $\mathrm{MD}=$ median; $\mathrm{SD}=$ standard deviation; Min=minimum; Max=maximum

Table 5 presents the results of the non-parametric Mann-Whitney test, with a significance level of $p \leq 0.05$, used to compare the following variables: number of people

per family, INSS benefits, religious and emotional support, support from friends and neighbors, and support received from family members between the two neighborhoods.

Table 5 - Comparison between Neighborhoods 1 and 2 in a Brazilian upcountry town according to number of people by family and type of support received -2009

\begin{tabular}{lccl}
\hline & $\mathbf{Z}$ & $\mathbf{p}$ & Significance \\
\hline Number of people/family & 0.24 & 0.81 & No significant difference \\
INSS Benefit & 1.25 & 0.21 & No significant difference \\
Religious Support & 0.14 & 0.89 & No significant difference \\
Emotional Support & 0.22 & 0.83 & No significant difference \\
Support from friends and neighbors & 1.87 & 0.06 & No significant difference; Neighborhood 1 presented a trend to attribute higher values \\
Family Support & 0.76 & 0.45 & No significant difference \\
\hline
\end{tabular}

Non-parametric Mann-Whitney test

No statistically significant differences were found between the values residents attributed in relation to benefits received from the INSS and their perceptions concerning religious, emotional and family support. The statistical test indicated that the residents from Neighborhood 1 tended to perceive the support received from friends and neighbors better. And there was no significant difference between the two neighborhoods in relation to the number of members per family.

\section{DISCUSSION}

This study seeks to disclose perceptions of support through the reports of the largest possible number of family members, thus contributing to expand knowledge about social support found in the literature, whose reports are from a single family member.

We expected to obtain statistically significant different results in relation to the perceptions of social support received by residents of two neighborhoods with different socioeconomic levels and clinical risks. However, the results did not show this. Statistical analysis revealed that there was no statistically significant difference between the neighborhoods concerning the number of people per family, amount of social security benefits received, religious and emotional support, or support from friends and neighbors reported by families. We expected that residents of Neighborhood 2, in which $88.2 \%$ of families were classified as being at medium and high risk, would have received more INSS benefits, the most important source of social assistance provided by the Brazilian government, than the residents of Neighborhood 1, mainly composed of families at low or no risk $(87,7 \%)$. Instrumental support evaluated in this study through the benefits received from the National Institute of Social Security (INSS) would permit better social interaction by raising living standards. Although more residents from Neighborhood 2 (37.3\%) were recipients of INSS benefits than from Neighborhood 1 (25.5\%) in this study, no statistically significant differences $(p=0.21)$ were found. This indicates that government support is relatively similar in both neighborhoods. A study ${ }^{(4)}$ addressing the association between socioeconomic situation, support and support networks concluded that the lack of social support and networks is more frequently verified with socially and economically disadvantaged people.

Among governmental social policies, social security is one of the most important resources to improve the 
population's health conditions. Indirectly, it is expected to improve the living conditions of the more deprived population, thus helping to increase their budget. This is in agreement with the recommendations in the Final Report of the National Commission on Social Determinants of Health ${ }^{(19)}$, which acknowledges erosion of social capital as an important factor, capable of causing a negative impact on health conditions. Instrumental support works as a palliative measure, meeting the needs of families at greater risk ${ }^{(2)}$.

The statistical test did not reveal a statistically significant difference between the two neighborhoods concerning support from friends and neighbors, but residents of Neighborhood 1 reported a higher perception concerning this type of support.

Families from the two neighborhoods, regardless of the socioeconomic or clinical conditions of their members, seem to attribute the same meaning to the religious support received. Our study agrees with the literature in that faith, religion and spirituality are considered important resources to strengthen family bonds and help families to cope with crises ${ }^{(14)}$. No significant differences were found in the reports of perceived emotional support between the different groups at risk, which means that family members from different risk groups consider this type of support of equal importance. Studies suggest that two hypotheses can explain the function of support: one hypothesis stresses that emotional support reduces the different levels of stress (buffering hypothesis); the other considers that relationships that generate support promote well-being even in the absence of stress (positive effects hypothesis) $)^{(19)}$.

No statistically significant differences were identified concerning perceived family support among individuals from the two neighborhoods. According to the literature, family support is directly and positively linked to health promotion ${ }^{(20)}$. Among the most well-known social networks, people report that the family provides most help. People who belong to functional families frequently report higher levels of health due to the emotional and material resources available. Although family support is considered the primary source of support to patients ${ }^{(21)}$, it may not be the only one or the main source of support: friends, neighbors, health professionals, caregiver homes or self-help groups may be the main support for some individuals ${ }^{(1,22)}$.

In relation to support from friends and neighbors, the statistical test revealed that there was no significant dif- ference shown in the perception of this type of support among residents of the two neighborhoods, although a trend was observed among Neighborhood 1 residents to relate higher values. Since families of Neighborhood 1 were classified as having a better socioeconomic and clinical condition, we can consider that families in better living conditions evaluate support received from friends and neighbors more highly. A study carried out in the USA showed a positive association between perceived support from friends and neighbors and self-assessed physical and mental health in a sample of Latin residents in the USA ${ }^{(20)}$.

\section{CONCLUSION}

This study compared the perceived social support reported by residents of two neighborhoods with different socioeconomic and clinical characteristics. We initially expected that the residents of the less fortunate neighborhood would perceive higher instrumental and family support. However, the results indicate no significant differences among the different types of social support perceived by residents from the two neighborhoods. All groups scored highly in regard to social support, which all families perceive strongly, regardless of their level of risk.

Both sites' residents perceived all types of social support as important. The values attributed to all types of support were above average, except support from friends and neighbors, which could mean that social support is important (essential) to all families.

We sought to discuss the results, emphasizing differences and similarities in relation to the literature; this task was hindered, however, by the lack of the same type of studies and by the instruments to measure social support. Despite the efforts of Brazilian researchers in recent years to include social, economic, and cultural aspects in epidemiological studies and, given the social determinants in the health-disease continuum, dimensions related to social support are still poorly explored.

This study's results are limited due to the sample size and the cultural characteristics of the setting. Thus, caution is warranted in trying to generalize the findings to populations of other countries. The measurement of informative and appraisal support can be noted as a limitation of this study. We suggest that the analysis of these support dimensions be deepened in another study. Further studies addressing the perceived social support received are needed as an essential resource to define public policies focused on health promotion.

\section{REFERENCES}

1. Fachado AA, Martinez AM, Villalva CM, Pereira MG. Adaptação cultural e validação da versão portuguesa. Questionário Medical Outcomes Study Social Support Survey (MOS-SSS). Acta Med Portug. 2007;20(6):525-33.
2. Gorman BK, Sivaganesan A. The role of social support and integration for understanding socioeconomic disparities in selfrated and hypertension. Soc Sci Med. 2007;65(5):958-75. 
3. Litwin H. Social network type and health status in a national sample of elderly Israelis. Soc Sci Med. 1998;46(4-5):599-609.

4. Weyers S, Dragano N, Möbus S, Beck EM, Stang A, Möhlenkamp $S$, et al. Low socio-economic position is associated with poor social networks and social support: results from the Heinz Nixdorf Recall Study. Int J Equity Health. 2008;7(1):7-13.

5. Antonucci TC. Social support, psychology of. In: Smelser NJ, Baltes PB, editors. International Encyclopedia of the Social \& Behavioral Sciences. New York: Elsevier Science; 2004. p. 14465-9.

6. Bolin K, Lindgren B, Lindström M, Nystedt P. Investments in social capital: implications of social interactions for the production of health. Soc Sci Med. 2003;56(12):2379-90.

7. Santos FJA. Estrutura de posições de classe no Brasil: mapeamento, mudanças e efeitos na renda. Belo Horizonte: Universidade Federal de Minas Gerais; 2002.

8. Nascimento AM. População e família brasileira: ontem e hoje. Apresentado no 15 Encontro Nacional de Estudos Populacionais da Associação Brasileira de Estudos Populacionais; 2006; Caxambu, MG, Brasil [Internet]. [citado 2010 nov. 15]. Disponível em: http://www.nomads.usp.br/disciplinas/SAP5846/ populacao_familia_nascimento_abep06.pdf

9. Buss PM, Pellegrini-Filho A. Iniquidades em saúde no Brasil, nossa mais grave doença: comentários sobre documento de referência e os trabalhos da Comissão Nacional sobre Determinantes Sociais da Saúde. Cad Saúde Pública. 2006;22(9):2005-8.

10. Brasil. Ministério de Saúde; Secretaria de Assistência à Saúde, Coordenação de Saúde da Comunidade. Saúde da Família: uma estratégia para a reorientação do modelo assistencial. Brasília; 1997.

11. Escola de Saúde Pública do Estado de Minas Gerais (ESPMG). Implantação do Plano Diretor da Atenção Primária à Saúde. Saúde em Casa. Oficina 3. Guia do participante [Internet]. Belo Horizonte; 2008 [citado 2010 nov. 15]. Disponível em: http://www.esp.mg.gov.br/wp-content/uploads/2009/04/ pdaps-oficina3-participante.pdf

12. Green J, Thorogood N. Qualitative methods for health research. London: Sage; 2004.
13. Bullock K. Family social support. In: Bomar PJ, organizador. Promoting health in families: applying family research and theory to nursing practice. 3rd ed. Philadelphia: Saunders; 2004. p.142-61.

14. McSherry W, Cash K, Ross L. Meaning of spirituality: implications for nursing practice. J Clin Nurs. 2004;13(8):934-41.

15. Griep R H. Confiabilidade e validade de instrumentos de medida de rede social e de apoio social utilizados no estudo pró-saúde [dissertação]. Rio de Janeiro: Escola Nacional de Saúde Pública; 2003.

16. Griep RH, Chor D, Faerstein E, Lopes C. Apoio social: confiabilidade teste-reteste de escala no Estudo Pró-Saúde. Cad Saúde Pública. 2003;19(2):625-34.

17. Griep RH, Chor D, Faerstein E, Werneck GL, Lopes CS. Validade de constructo de escala de apoio social do Medical Outcomes Study adaptada para o português no Estudo PróSaúde. Cad Saúde Pública. 2005;21(3):703-14.

18. Wright LM, Leahey M. Nurses and families: a guide to family assessment and intervention. 4th ed. Philadelphia: FA Davis; 2005.

19. Brasil. Ministério da Saúde, Comissão Nacional sobre Determinantes Sociais da Saúde (CNDSS). As causas sociais das iniquidades em saúde no Brasil: relatório final [Internet]. Rio de Janeiro: FIOCRUZ; 2008. Disponível em: http://portal. saude.gov.br/portal/arquivos/pdf/determinantesdesauderelatorio.pdf

20. Mulvaney-Day NE, Alegría M, Sribney W. Social cohesion, social support, and health among Latinos in the United States. Soc Sci Med. 2007;64(2):477-95.

21. Ell K. Social networks, social support and coping with serious illness: the family connection. Soc Sci Med. 1996;42(2):173 83.

22. Silverio C D, Dantas RAS, Carvalho AR S. Gender-specific evaluation of coronary disease patients' self-esteem and social support. Rev Esc Enferm USP [Internet]. 2009 [cited 2010 Dez 14];43(2):407-14. Available from: http://www.scielo.br/pdf/reeusp/v43n2/en_a21v43n2.pdf

\section{Acknowledgments}

To the participants, family members, the administrators of the Primary Care Family Health Service Unit and the examination board, who made it possible to conduct this study. Acknowledgements also for partial funding from the Brazilian Council for Scientific and Technological Development (CNPq). 